\title{
Optimization Model of Small-Scale Chicken Production in Cambodia
}

\author{
Darith Siek1,2, Shiwei Xu1 ${ }^{*}$, Wen Yu1 ${ }^{1}$ Abdul-Gafar Ahmed1', Chamroeun Din² \\ ${ }^{1}$ Agricultural Information Institute, Chinese Academy of Agricultural Sciences, Beijing, China \\ ${ }^{2}$ Regional Polytechnic Institute Techo Sen Battambang, Ministry of Labor and Vocational Training, Battambang, \\ Battambang Province, Cambodia \\ Email: *xushiwei@caas.cn
}

Received 21 May 2016; accepted 28 May 2016; published 31 May 2016

Copyright (C) 2016 by authors and Scientific Research Publishing Inc.

This work is licensed under the Creative Commons Attribution International License (CC BY). http://creativecommons.org/licenses/by/4.0/

(c) (i) Open Access

\section{Abstract}

These study attempts analyze the chicken production scale in Battambang of Cambodian among the rural household rice farmers using Optimization Model. The study explains the explicit opportunity cost of not investing time and other reliable resources in the chicken (courtyard) production is the income the farmer would have gained competitively in the market price of chicken. The results suggest that two out of 6 districts have the potential to obtain optimal scale by increasing chicken head counts. High chicken death rate was detected in the region thus the authors suggests a subsidy policy for disease control should be provided to affected region or high risk region; and locally, there should be broader extension services orienting farmers on the proper management of small scale chicken production.

\section{Keywords}

Chicken, Production Scale, Optimization Model, Cambodia

\section{Introduction}

Recently Cambodia has been named as one of the new tiger economies of Asia following the five years high economic growth of about 7\% GDP growth rate from 2013 to 2017 (ADB, 2016) [1]. Cambodian is largely known as an agricultural economy where agricultural contributes about $31.6 \%$ to the national GDP and majority of these effort comes from the rural household farmers. The livestock subsector has been gaining the attention of researchers and the government of Cambodia in the past years as this sector faces both external and internal challenges such as spread of diseases, high cost of inputs and low access to capital. Despite these challenges, the

${ }^{*}$ Corresponding author. 
livestock subsector has shown notable increase in livestock production. According to MAFF (2015) [2], the livestock production increased from 34.81 million heads in 2013 to about 36.93 million heads in 2015 and projected to about 40.34 million in year 2018. Poultry production is a common trait in every Cambodian household as it provides instant protein and quick cash to the family. In Cambodia, the number poultry has been increase since 2013 according to MAFF (2015) [2]. The ministry projected the increase to reach about 33.2 million head in year 2018. The provincial demand for chicken in Cambodia varies in accordance to the size and economic potential of the province. On average, AsiaDHRRA (2008) [3] estimated that the demand for chicken per district is from $200 \mathrm{~kg}$ to $500 \mathrm{~kg}$ per day. Chicken meat is an essential protein intake for Cambodians. Averagely, a household demand about 1 to $1.5 \mathrm{~kg}$ of chicken meat for meal preparation.

This study focuses on chicken production with respect to the feed structure which in this case is the rice produced by the household. Majority of the rural household farmers in Cambodia produces crops and livestock concurrently, and the produce in the farm are used as feed for the livestock. The study employs optimization model for analysis. The outcome of the analysis is expected to provide the rural famers with effective methods to proper manage their production scale efficiently.

\section{Data Resource and Description}

About 204 were interviewed using a structured questionnaire in Battambang province of Cambodia under which 6 districts, 12 communes with 18 villages were covered. Animal rearing farmers were deliberately selected as sample for the study. The questionnaires were administered by the authors and some student from AII-CAAS, UME and RUA. Battambang is one of the largest rice producing region in Cambodia with farmers simultaneously engaging is livestock production as farm product can be used as feed or source of feed. Among the 204 farmer households interviewed about 132 households rear chicken.

Moreover, as show in Table 1 below, the highest average chicken number is in Thmakoul and Sangkae district with about 35 head per household followed by Banan, Ratanak and Mondol with 33, 29 and 27 head/household respectively. The average family number is between 4 to 5 persons consisting of 3 to 4 laborer per households. Very few members of the households work outside. Chicken death rate is high in most of the districts; the highest death rate is seen in Thmakoul (29\%) followed by Banan 27\%, AekPhnum 22\% and Ratanak Mondol 21\%.

Table 2 shows the summary statistics of the key factors used in the model that is the price (revenue and cost) and feed structure (rice). For a rational farmer, it is expected to either reduce cost or maximize profit. Cost and revenue are the two essential aspects for any management system. To the Cambodian farmers, revenue accrues from the same of their chicken and/or sale of the eggs while other cost includes feed, healthcare services. The household chicken are usually small in size and thus does not carry much weight for higher price another reason is that most of these household chicken are purchased by neighbors or even family members thus are sold in relatively low prices. For instance, in the study area on average a chicken cost only 4.03 dollars. The market cost per $\mathrm{kg}$ is about 4.65 to 7.5 dollars per kg which (Khieu et al. 2009) [4] which is much higher compared to the 4.03 dollars per head in the surveyed area. The cost met for the rural household include feed cost, diseased of livestock (date rate) also the healthcare services. Moreover, the courtyard production system among the rural farmers gains time and financial investment which results to the above drawbacks.

Table 1. Information of respondents in six district.

\begin{tabular}{clccccc}
\hline $\mathrm{N}^{\mathrm{0}}$ & \multicolumn{1}{c}{ Districts } & Household sample & $\begin{array}{c}\text { Household with } \\
\text { chicken }\end{array}$ & $\begin{array}{c}\text { Average chicken per } \\
\text { household }\end{array}$ & $\begin{array}{c}\text { Chicken death } \\
\text { rate }\end{array}$ & $\begin{array}{c}\text { Average family } \\
\text { number }\end{array}$ \\
\hline 1 & Aek Phnum & 39 & 20 & 20 & $22 \%$ & 4.7 \\
2 & Banan & 31 & 24 & 33 & $27 \%$ & 4.5 \\
3 & Moung Ruessei & 37 & 23 & 27 & $17 \%$ & 4.2 \\
4 & Ratanak Mondol & 20 & 16 & 29 & $21 \%$ & 4.5 \\
5 & Sangkae & 47 & 23 & 35 & 35 & 4.5 \\
6 & Thma Koul & 30 & 26 & 30 & $29 \%$ & 4.9 \\
& Total & 204 & 132 & $22 \%$ & 4.5 \\
\hline
\end{tabular}


Table 2. Summary of key price and inputs used for the base scenario.

\begin{tabular}{lcc}
\hline \multicolumn{1}{c}{ Input } & \multicolumn{2}{c}{ Value } \\
\cline { 2 - 3 } & Dollars \\
\hline Price of rice as chicken feed $(* 1000$ riel/kg ) & 0.789 & 0.19 \\
Price of sell chicken(*1000 riel/kg ) & 16.119 & 4.03 \\
Chicken death rate (\%) & & 7.72 \\
Average total riceoutput (ton) & $72 \%$ \\
Rice outputsold (\%) & $21 \%$ \\
Rice output used for food(\%) & $7 \%$ \\
Rice output used for animal feed and seed & & \\
\hline
\end{tabular}

As mentioned earlier, most of the farmers interviewed are crop farmers, specifically rice farmers. About $72 \%$ of their rice output are sold (usually for quick income); $21 \%$ of the output are consumed as food while the remaining portion are used as feed for their livestock and little portion kept as seed for next season.

\section{Model Description}

The household chicken production or in other words "courtyard production" are usually in small scale and not at optimal output. This study attempts to establish an econometric linear programming model to analyze the chicken production among the rural farmers in Cambodia. Optimization model was employed to analyze the production scale.

The objective function

$$
\begin{aligned}
& M a x Y=P . Q-m . w . \gamma \cdot Q-0.5 Q . \delta . P \\
& \text { subject to } \quad m=5 \\
& \gamma=3 \\
& \text { 5.3.Q.w } \leq r_{\text {total }}-r_{\text {food }}-r_{\text {sale }}
\end{aligned}
$$

Put $\alpha$ multiplier of (4) we can get

$$
\begin{aligned}
& F=P . Q-5.3 . Q . w-0.5 Q \delta P-\alpha\left(5.3 . Q . w-r_{\text {total }}+r_{\text {food }}+r_{\text {sale }}\right) \\
=> & \frac{\partial F}{\partial Q}=P-5.3 . w-0.5 \delta P-\alpha(5.3 . w)=0
\end{aligned}
$$

From (5) we can get

$$
\alpha=\frac{P(1-0.5 \delta)}{5.3 . w}-1
$$

By (6) it can be seen $\alpha \neq 0$, meet with Karush-kuhn-Tucker (KKT) condition, from (4) optimization algorithms can be established as methods for numerically solving the KKT system of equations.

$$
Q^{*}=\frac{r_{\text {total }}-r_{\text {food }}-r_{\text {sale }}}{5.3 . w}
$$

The optimization model was basically exploring the income and potential scale for the rural household chicken production. The multiplicity of the function concentrates on the ratio of real chicken size, death rate and feed structure. The multiplicity function explained in the above model includes the property value of chicken (end of

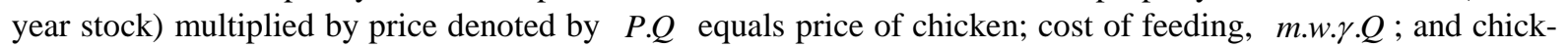
en death rate $0.5 Q . \delta . P$. The result of the model is tabulated in the Table 3. 
Table 3. Description of the acronyms used in the optimization algorithm.

\begin{tabular}{ll}
\hline Acronyms & Description \\
\hline $\mathrm{Y}$ & Family Income or Net Income \\
$\mathrm{P}$ & Chicken's Price (unit 1000 riel/head ) \\
$\mathrm{Q}$ & Average number of chicken stock in 2015 \\
$\mathrm{~m}$ & Month of rice as the chicken's feed use \\
$\gamma$ & Price of rice for chicken (unit 1000 riel $/ \mathrm{kg})$ \\
$\delta$ & Consumption of rice for chickenfeedper month per head $(\mathrm{kg})$ \\
$r_{\text {total }}$ & The ratio of chicken death \\
$r_{\text {food }}$ & Rice total output \\
$r_{\text {sale }}$ & Rice used for food \\
\hline
\end{tabular}

Table 4. Optimum result of chicken small-scale production.

\begin{tabular}{|c|c|c|c|c|c|}
\hline \multirow{2}{*}{$\mathrm{N}^{0}$} & \multirow{2}{*}{ District } & \multirow{2}{*}{$\mathrm{Q}$} & \multirow{2}{*}{$\mathrm{Q}^{*}$} & \multicolumn{2}{|c|}{$\mathrm{Y}$} \\
\hline & & & & $(* 1000$ riel $)$ & Dollars \\
\hline 1 & Aek Phnum & 20 & 19 & 32 & 8 \\
\hline 2 & Banan & 33 & 22 & 66 & 17 \\
\hline 3 & Moung Ruessei & 27 & 30 & 107 & 27 \\
\hline 4 & Ratanak Mondol & 29 & 21 & 84 & 21 \\
\hline 5 & Sangkae & 35 & 26 & 61 & 15 \\
\hline \multirow[t]{2}{*}{6} & Thma Koul & 35 & 37 & 61 & 15 \\
\hline & Average & 30 & 26 & 69 & 17 \\
\hline
\end{tabular}

\section{Results}

Given the farmers income from their chicken production, the model expresses the optimal scale of production. As shown in Table 4, the model suggest that the farmers in 2 districts (Thma Koul and Moung Ruessei) can increase their scale of production as their actual or real chicken head count (Q) is less than the expected head count $\left(Q^{*}\right)$. The largest difference between the actual and expected chicken head count is seen in Banan $(-22)$ and Sangkae (-9). In these districts (Banan and Sangkae), the model suggest reduction in the scale of the backyard chicken production. Some of the reason could be as a result of the low income and high death rate. MAFF (2016) [5] announced the potential heat waves and diseases affecting livestock (especially chicken) in most region of Cambodia

\section{Conclusion and Discussion}

Optimization model was used to investigate the production scale of Cambodian rural household farmers of Battambang rearing chicken in complement with rice production. The farmers use their farm produce (rice) as feed to sustain the chicken production. The result shows that in general, for optimal production scale, the study suggest the Battambang farmers should cut down about 13\% of their chicken head count. The likely reason for this is that majority of the farmers (if not all) practicing courtyard chicken production pays less attention to the proper management system more so they invest little resources to the production. Thus, with these drawbacks, the farmers experiences high death rate and low meat. The study also explains the explicit opportunity cost of not investing time and other reliable resources in the chicken (courtyard) production is the income the farmer 
would have gained competitively in the market price of chicken. Among the 6 district in the Battambang province, Thma Koul and Moung Ruessei shows potentials of increasing their production scale in contrast to other 4 districts. Given the high death rate found in this study, the authors suggests a subsidy policy for disease control to affected region and locally, there should be broader extension services orienting farmers on the proper management of small scale chicken production.

\section{Acknowledgement}

This paper was supported by the CAAS Science and Technology Innovation Project (number: CAAS-ASTIP2015-AII), founded by Chinese Academy of Agricultural Sciences and Technology.

\section{References}

[1] ADB (2016) Asian Development Outlook 2016. Asia’s Potential Growth. Mandaluyong City. http://www.adb.org/sites/default/files/publication/182221/ado2016.pdf

[2] MAFF (2015) Agricultural Sector Strategic Development Plan 2014-2018, Ministry of Agriculture Forestry and Fisheries, Kingdom of Cambodia.

[3] AsiaDHRRA (2008) Value Chain Analysis Report: Cambodia, Philippines, Vietnam. Linking Small Farmers to Market Project. Published by Asian Partnership for the Development of Human Resources in Rural Asia (AsiaDHRRA) and the ASEAN Foundation. http://asiadhrra.org/activityblogs/2ndlsfmrtw/lsfmvaluechain2.pdf

[4] Khieu, B., Pok, S. and Olaf, T. (2009) Assessment of Poultry Markets and Sellers in 25 Provinces and Cities of Cambodia. Food Agriculture and Organization (FAO). AHBL - Promoting Strategies for Prevention and Control of HPAI. Rome.

[5] MAFF (2016) Instruction and Announcement about "The Save and Prevention Animal from Disease Caused by Drought/Dry”, Ministry of Agriculture Forestry and Fisheries, Cambodia. (Cambodia Language). Facebook Page: Spokesperson of the Ministry of Agriculture, Forestry and Fisheries. 